\title{
Screening of Chemical Composition, Antioxidant and Anticholinesterase Activity of Section Brevifilamentum of Origanum (L.) Species
}

\section{Hasibe Yılmaz ${ }^{1}$, Sema Çarıkçı ${ }^{2 *}$, Turgut Kılıç ${ }^{3}$, Tuncay Dirmenci ${ }^{4}$, Turan Arabacı ${ }^{5}$ and Ahmet C. Gören ${ }^{\circledR 1}$}

${ }^{1}$ TUBITAK National Metrology Institute (UME), Department of Chemistry, Gebze-Kocaeli, Türkiye

${ }^{2}$ Balıkesir University, Faculty of Sciences and Arts, Department of Chemistry, Campus of Çă̆ış, -Balıkesir, Türkiye

${ }^{3}$ Balıkesir University, Necatibey Education Faculty, Department of Science Educations, Balıkesir, Türkiye

${ }^{4}$ Ballkesir University, Necatibey Education Faculty, Department of Biology Educations, Balıkesir, Türkiye

${ }^{5}$ Inonu University, Faculty of Pharmacy, Department of Pharmaceutical Botany, Malatya, Türkiye (Received April 19, 2017; Revised May 17, 2017; Accepted May 25, 2017)

\begin{abstract}
Six Origanum species, Origanum acutidens (Hand. -Mazz.) Ietsw. (OA), Origanum brevidens (Bornm.) Dinsm. (OB), Origanum haussknechtii Boiss. (OC), Origanum husnucan-baseri H.Duman, Aytaç \& A.Duran (OHB), Origanum leptocladum Boiss. (OL), Origanum rotundifolium Boiss. (OR), belonging to sect. Brevifilamentum were analyzed for their essential oil and phenolic components. For the essential oil analyses, GC-MS and GC-FID were used. Phenolic contents of the aerial parts of the chloroform, acetone, and methanol extracts were analyzed using LC-MS/MS. Antioxidant activity of the species was investigated by three methods; DPPH free radical scavenging activity, $\beta$-carotene linoleic acid assays and CUPRAC assays. Also, acetyl and butyrylcholinesterase inhibition of the extracts were investigated. While the essential oil contents of the section Brevifilamentum showed difference in chemotype, the phenolic contents were found to be coumaric acids and derivatives. These groups were the most abundant components of the extracts. Especially rosmarinic acid was detected in high amounts in acetone and methanol extracts. OA had the best activity both in antioxidant and anticholinesterase assays.
\end{abstract}

Keywords: Origanum; Bravifilamentum; essential oil; phenolics; antioxidant activity; anticholinesterase activity. (C) 2017 ACG Publications. All rights reserved.

\footnotetext{
*Corresponding author: E-Mail: carikci@ balikesir.edu.tr; Phone:090-266-6121278, Fax:090-266-6121215.
} 


\section{Introduction}

Aromatic plants are often used in traditional medicine due to their beneficial long-term effects on health for prevention and treatment of different diseases. They have also been used as cooking ingredients for their flavoring quality since ancient times [1]. Many of these plants belong to the family of Lamiaceae (Labiatae), which has a very intense expansion throughout the world; they are predominately distributed around the Mediterranean region, consisting of about 7200 species and 236 genera. According to the recent studies, it is the third largest family in Turkey with 46 genera and about 600 species (ca. 750 taxa), approximately 350 of which are endemic to Turkey and the endemism rate is about $44 \%$ [2-6].

One of the most used Lamiaceae members is Origanum. They are known as "kekik" in Turkey, "oregano" in the world. Origanum has 43 species (51 taxa) and 15 hybrids worldwide [7-12]. Most of its species are distributed in Turkey. Origanum comprises 23 species (26 taxa) and eight hybrids in Turkey, 20 of which are endemic. The species are mainly concentrated in the Mediterranean area of Turkey. Section Brevifilamentum Ietsw., which is the main material of this study was characterized by leathery leaves, large and nodding spikes and 2-lipped calyces. Section Brevifilamentum consists of 6 species, 5 of which are endemic to Turkey: Origanum acutidens (Hand. -Mazz.) Ietsw. (endemic), O. brevidens (Bornm.) Dinsm. (endemic), O. haussknechtii Boiss. (endemic), O. husnucan-baseri H.Duman, Aytaç \& A.Duran (endemic), O. leptocladum Boiss. (endemic) and $O$. rotundifolium Boiss.

The oregano is used as a condiment or herbal tea. Moreover, its essential oil (Origanum oil, kekik yağı) and hydrosol (Origanum water, kekik suyu) are produced from dried oregano and have been used in traditional medicine to treat some diseases such as gastric ulcers, diarrhea, blood cholesterol, glucose level and pain in rheumatism [13].

Many phytochemical studies have been conducted to investigate the chemical profiles and activities of Origanum species. The studies especially focused on essential oil profiles and showed oregano essential oils to be rich in phenolic compounds, like carvacrol and thymol [13, 14]. Additionally, extract of the species includes phenolics such as rosmarinic acid, caffeic acid, ferulic acid, apigenin, luteolin, salvigenin and catechin [15-17]. Biological activities of the species and their extracts have also been described such as antioxidant, antimicrobial, antifungal, antispasmodic, antitumoral, analgesic, antimutagenic, angiogenic, antiparasitic, antiplatelet and anti-elastase [18]. In Brevifilamentum section, the studies especially focused on two species, i.e. $O$. acutidens and $O$. rotundifolium. Chemical profile [19-22] and insecticidal [23-29], antioxidant [30-33], antimicrobial and antibacterial [34-36] activities of the essential oils and some extracts were studied. It has been reported that essential oil of $O$. acutidens was found to be insecticidal due to its high concentration of carvacrol. Essential oils of O. haussknechtii [37], O. husnucan-baseri [38] were also reported to show antibacterial activity [39] and O. leptocladum [22, 40-41].

The present study is on identification, quantification and evaluation of antioxidant and anticholinesterase activities of essential oils and phenolic constituents of extracts of six Origanum species, belonging to section Brevifilamentum. Although there are numerous reports on the essential oils of the species, this is the first report on the analysis of phenolic composition and antioxidant and anticholinesterase activities of the extracts.

\section{Materials and Methods}

\subsection{Plant Material}

Collection location, coordinates and time of the Origanum species are given in the Table 1. The species were identified by Dr. Tuncay Dirmenci at Balıkesir University. Voucher specimens were deposited at the Herbarium of Faculty of Education, Balıkesir University, Balıkesir, Turkey. 
Table 1. List of the Origanum species with locality, altitude and collection time.

\begin{tabular}{|c|c|c|c|c|c|}
\hline Code & $\begin{array}{c}\text { Herbarium } \\
\text { no }\end{array}$ & Species & Locality and Coordinates & $\begin{array}{l}\text { Altitude } \\
\text { (m) }\end{array}$ & Year \\
\hline OA & T.A. 2825 & Origanum acutidens & $\begin{array}{c}\text { Malatya: Between } \\
\text { Gündüzbey and Kozluk 3rd } \\
\text { km, rocky slopes }\end{array}$ & 1000 & 2013 \\
\hline OB & T.D. 4270 & Origanum brevidens & $\begin{array}{l}\text { Osmaniye : Between } \\
\text { Yarpuz and Yağlıpınar; } \\
\text { N } 37.01064 \\
\text { E } 36.27651\end{array}$ & 1310 & 2014 \\
\hline $\mathrm{OH}$ & T.A. 2824 & $\begin{array}{c}\text { Origanum } \\
\text { haussknechtii }\end{array}$ & $\begin{array}{c}\text { Erzincan: Between } \\
\text { Kemaliye and Arapkir, } \\
\text { 15th-20th km, calcareous } \\
\text { rocks } \\
\text { N } 39.153170 \\
\text { E } 38.620290\end{array}$ & 1097 & 2013 \\
\hline OHB & T.D. 4298 & $\begin{array}{l}\text { Origanum husnucan- } \\
\text { baseri }\end{array}$ & $\begin{array}{c}\text { Between Alanya and } \\
\text { Gökbel plateau, 43rd km; } \\
\text { Kuşyuvası area, tunnels } \\
\text { N } 36.55894 \\
\text { E } 32.34865\end{array}$ & 1352 & 2014 \\
\hline OL & T.D. 4290 & Origanum leptocladum. & $\begin{array}{c}\text { Karaman: Between } \\
\text { Ermenek and Kazanc1, } \\
\text { Görmeli village, above 1st } \\
\text { km; } \\
\text { N } 36.54299 \\
\text { E } 32.96344\end{array}$ & 885 & 2014 \\
\hline OR & T.D. 3943 & $\begin{array}{c}\text { Origanum } \\
\text { rotundifolium }\end{array}$ & $\begin{array}{c}\text { On the road of Artvin - } \\
\text { Ardanuç } \\
\text { N } 41.193790 \\
\text { E } 41.867840\end{array}$ & $600-700$ & 2013 \\
\hline
\end{tabular}

\subsection{Chemicals}

Chloroform, acetone, and methanol were used for the preparation of the extracts. Following compounds were used as standards in LC-MS/MS analysis: fumaric acid (99\%, Sigma-Aldrich ), pyrogallol (98\%, Sigma-Aldrich), rutin (94\%, Sigma-Aldrich), chlorogenic acid (95\%, SigmaAldrich), gallic acid (99\%, Merck), syringic acid (95\%, Sigma-Aldrich), (E)-ferulic acid (99\%, Sigma-Aldrich), caffeic acid (98\%, Sigma-Aldrich), pelargonin chloride (98\%, Sigma-Aldrich), quercitrin (97\%, Sigma-Aldrich ), salicylic acid (99\%, Sigma-Aldrich), $p$-coumaric acid (98\%, Sigma-Aldrich), luteolin-7-O-glu (99\%, AppliChem), rosmarinic acid (96\%, Sigma-Aldrich), pyrogallol (98 \%, Sigma-Aldrich), apigenin (95\%, Sigma-Aldrich), kaempferol (96\%, SigmaAldrich) and isorhamnetin (98\%, Extra Synthese, Genay-France). Stock solutions were prepared as $10 \mathrm{mg} / \mathrm{L}$ in methanol. HPLC grade methanol was purchased from Merck (Darmstadt, Germany). Calibration solutions were prepared in methanol in a linear range. Dilutions were performed using automatic pipettes and glass volumetric flasks (A class). $100 \mathrm{mg} / \mathrm{L}$ curcumin solution was freshly prepared, from which $50 \mu \mathrm{L}$ was used as an Internal Standard (IS) in all experiments. 


\subsection{Essential oil}

The air-dried aerial parts of Origanum species (100 g of each) were subjected to hydro distillation with water for $4 \mathrm{~h}$, using a Clevenger-type apparatus to produce the essential oil. Essential oil yields of species are $0.81,1.29,0.70,0.62,0.76$ and 0.16 from $\mathrm{OA}, \mathrm{OB}, \mathrm{OH}, \mathrm{OHB}, \mathrm{OL}, \mathrm{OR}$, respectively.

\subsection{Gas chromatography-mass spectrometry $(G C-M S)$ and $G C$-flame ionization detector (GC-FID) conditions}

GC-MS was conducted on Thermo Electron Trace 2000 GC model gas chromatography and Thermo Scientific TSQ GC-MS/MS. A Phenomenex DB5 fused silica column (30 m x $0.32 \mathrm{~mm}$, with $0.25 \mu \mathrm{m}$ film thickness) was used with helium as a carrier gas at $1 \mathrm{~mL} / \mathrm{min}$ flow rate $(138 \mathrm{kPa})$. The GC temperature program was set as follows; $150{ }^{\circ} \mathrm{C}$ hold for $5 \mathrm{~min}$, ramp to $250{ }^{\circ} \mathrm{C}$ at $3{ }^{\circ} \mathrm{C} / \mathrm{min}$ and hold for $10 \mathrm{~min}$. The temperature of the MS transfer line was set to $230^{\circ} \mathrm{C}$. Using scan mode, a mass range from 50 to $650 \mathrm{~m} / \mathrm{z}$. The GC oven temperature was kept at $60{ }^{\circ} \mathrm{C}$ for $10 \mathrm{~min}$ and programmed to $220{ }^{\circ} \mathrm{C}$ at a rate of $4{ }^{\circ} \mathrm{C} / \mathrm{min}$ and then kept constant at $220{ }^{\circ} \mathrm{C}$ for $15 \mathrm{~min}$. The split ratio was adjusted to 1:20, the injection volume was $0.1 \mathrm{~mL}$ and EI/MS was recorded at $70 \mathrm{eV}$ ionization energy. Mass range was $m / z 35-500$ amu. A homologous series of $n$-alkanes was used as a reference in the calculation of Kovats Indices (KI). Identification of the compounds was based on the comparison of their Kovats Indices and mass spectra with those obtained from authentic samples and/or the NIST and Wiley spectra as well as the literature data [42-44]. GC-FID performed using Thermo Electron Trace GC-FID detector and same GC program was used as stated above.

\subsection{Preparation of Extracts}

Approximately 100 grams of shade-dried powdered plant samples were extracted with methanol (M) for 15 days. After filtration and evaporation, they named M1 for each plant samples. Also another 100 gram of the plant was extracted with chloroform (C) for 15 days. After filtration and evaporation, the residuary plant was extracted with acetone (Ac) and methanol for 15 days in the same way. They were named $\mathbf{C}, \mathbf{A c}$, and $\mathbf{M} 2$ for each species.

\subsection{Liquid Chromatography-Mass spectrometry}

LC-MS/MS experiments were performed by a Zivak ${ }^{\circledR}$ HPLC and Zivak ${ }^{\circledR}$ Tandem Gold Triple quadrupole (Istanbul, Turkey) mass spectrometry equipped with a Synergy Max C18 column ( $250 \times 2 \mathrm{~mm}$ i.d., $5 \mathrm{~mm}$ particle size). The mobile phase was composed of water (A, $0.1 \%$ formic acid) in methanol (B, $0.1 \%$ formic acid), the gradient programme of which was $0-1.00$ minute $55 \% \mathrm{~A}$ and $45 \% \mathrm{~B}, 1.01-20.00$ minutes $100 \% \mathrm{~B}$ and finally $20.01-23.0055 \% \mathrm{~A}$ and $45 \% \mathrm{~B}$. The flow rate of the mobile phase was $0.25 \mathrm{~mL} / \mathrm{min}$, and the column temperature was set to $30 \mathrm{oC}$. The injection volume was $10 \mathrm{~mL}$.

The best mobile phase solution was determined to be a gradient of acidified methanol and water system. Triple quadrupole mass spectrometry was used due to its fragmented ion stability [45]. The optimum ESI parameters were determined as $2.40 \mathrm{mTorr} \mathrm{CID} \mathrm{gas} \mathrm{pressure,} 5000.00 \mathrm{~V}$ ESI needle voltage, $600.00 \mathrm{~V}$ ESI shield voltage, $300.00{ }^{\circ} \mathrm{C}$ drying gas temperature, $50.00{ }^{\circ} \mathrm{C}$ API housing temperature, 55 psi Nebulizer gas pressure and 40.00 psi drying gas pressure. A detailed information on the experiment parameters is given in supporting information. 


\subsection{Preparation of test solution for LC-MS/MS}

To fifty $\mathrm{mg}$ of each extract in round bottom flask was added $4 \mathrm{~mL}$ of the ethanol-water mixture $(50: 50 \mathrm{v} / \mathrm{v})$. In order to obtain a good solubility, the flask was refluxed on a water bath until a clear solution was obtained. They were then transferred into a $5 \mathrm{~mL}$ of volumetric flask and diluted to volume. A portion of $1 \mathrm{~mL}$ of this stock solution was transferred into a $5 \mathrm{~mL}$ of another volumetric flask, and $50 \mathrm{~mL}$ of curcumin solution was added as internal standard and diluted to the volume with methanol and mixed. The solution was filtered through a $0.45 \mu \mathrm{m}$ Millipore Millex-HV filter and the final solution $(1 \mathrm{~mL})$ was transferred into a capped auto sampler vial and $10 \mathrm{~mL}$ of sample was injected to LC for each run. The samples in the auto sampler were kept at $15^{\circ} \mathrm{C}$ during the experiment.

\subsection{Validation of experiments and uncertainty evaluation}

Curcumin was used as an internal standard in validation experiments of all of the compounds. The validation parameters were determined to be linearity, repeatability, LOD (limit of detection) and LOQ (limit of quantification) experiments. The linearity for each compound for the reported method was determined by analyzing standard solution. The linearity ranges of each compound are given in Table 2 in supporting information. The correlation coefficients $\left(r^{2}\right)$ were found to be $\geq 0.99$. Linear regression equations of the reported compounds are also presented in supporting information. Detailed procedures of uncertainty evaluation were reported previously in the literature [45-47].

\subsection{Activity}

Inhibitory activities of acetyl- and butyrylcholinesterase were measured by a slightly modified spectrophotometric method, developed by Ellman, Courtney, Andres and Featherston [48-50]. Acetylthiocholine iodide and butyryl thiocholine iodide were used as substrates of the reaction, and DTNB method was applied for the measurement of the anticholinesterase activity [48-49]. The antioxidant activities were measured based on 2,2-diphenyl-1-picrylhydrazyl (DPPH) free radical scavenging activity, $\beta$-carotene linoleic acid assays and cupric $\left(\mathrm{Cu}^{2+}\right)$ ion reducing power assay (CUPRAC) [50-56]. The detailed procedure of the biological activities is given in Supplemental Material.

\section{Results and Discussion}

\subsection{Essential Oil}

The aerial parts of the six Origanum species belonging to section Brevifilamentum were analyzed by using GC-MS and GC-FID, 74 components of which were accounted for $94.1-99.8 \%$ of the total oil composition. The components were classified into 6 classes based on their chemical structures: hydrocarbons and derivatives, monoterpene hydrocarbons, oxygenated monoterpenes, sesquiterpene hydrocarbons, oxygenated sesquiterpenes, and phenolic compounds. Essential oil compositions of the species are given in Table 2.

The essential oil composition of Brevifilamentum section has been analyzed to have different chemotypes. OA was found to be rich in monoterpene hydrocarbons with the main compound of $\mathrm{m}$ cymene (39.2\%). Other compounds are allo-aromadendrene (24.8\%) and aromadendrene (11.8\%). In the previous studies, OA was reported as carvacrol type $[19,28]$. OB was found to be rich in phenolic compounds, and its main compounds were identified as carvacrol $(72.1 \%)$, carvone $(9.1 \%)$ and borneol (7.1\%). Carvacrol constitutes the major part of the oil, and the rest of the essential oil is rich in oxygenated monoterpenes. To the best of our knowledge, there has been no report on the essential oil composition of $\mathrm{OB}$, and the present study is the first study. $\mathrm{OH}$ and $\mathrm{OL}$ were rich in sesquiterpene hydrocarbons $(35.7 \%$ and $34.8 \%)$. Main compounds of the essential oil of $\mathrm{OH}$ and $\mathrm{OL}$ were aromadendrene (23.7\%) and $\tau$-murolene $(20.1 \%)$, respectively. 
Other main compounds were determined as carvacrol (16.2\%) and allo-aromadendrene $(15.2 \%)$ for $\mathrm{OH}$, and $p$-cymene $(17.1 \%)$ and borneol $(16 \%)$ for $\mathrm{OL}$. In the previous study, $\mathrm{OH}$ was found to be rich in $p$-cymene [37] and OL was reported in three different studies as $p$-cymene [40], carvacrol [41] and thymol/carvacrol type [22]. Another member of this section, OHB is rich in oxygenated monoterpenoids and its main compounds were cis- $\beta$-terpineol $(24.3 \%)$, menth-3-en-8-ol $(22.6 \%)$ and menthone (13.1\%). This species was previously reported as monoterpenoid-rich and the main compounds were borneol, $\alpha$-terpineol and trans-sabinene hydrate [38]. The last member of the section, OR was rich in oxygenated sesquiterpenoids, and its main compound was $\alpha$-cadinol $(27.8 \%)$. Other main compounds were found to be isopulegyl acetate (19.8\%), which has an oxygenated monoterpene structure and limonene oxide (15.3\%). It was reported in the literature that OR volatile oil was rich in monoterpenoids, and the main compound was cis-sabinene hydrate [20].

Previous studies showed that, the essential oils of the species had different chemical contents. The differences in the chemical composition of the oils might be related to local, climatic and seasonal differences $[13,20]$.

Table 2. Essential oil composition of Section Brevifilamentum

\begin{tabular}{|c|c|c|c|c|c|c|c|}
\hline Compounds & KI & $\mathbf{O A}$ & OB & OH & OHB & OL & OR \\
\hline \multicolumn{8}{|l|}{ Hydrocarbons and derivatives } \\
\hline 3-methyl-nonane & 971 & - & - & - & - & $\mathrm{t}$ & - \\
\hline 1-octen-3-ol & 979 & - & 0.4 & - & - & 0.6 & - \\
\hline 3-octanol & 991 & - & 0.4 & - & - & 0.2 & - \\
\hline 2-methyl-decane & 1063 & - & 1.0 & - & - & - & - \\
\hline undecane & 1100 & - & 0.3 & - & - & 0.2 & - \\
\hline menth-3-en-8-ol & 1150 & - & - & - & 22.6 & - & - \\
\hline geranyl butyrate & 1564 & - & - & 4.5 & - & - & - \\
\hline \multicolumn{2}{|l|}{$\%$ identified } & - & 2.1 & 4.5 & 22.6 & 1.0 & - \\
\hline \multicolumn{8}{|l|}{ Monoterpene hydrocarbons } \\
\hline$\alpha$-thujene & 930 & - & - & - & $\mathrm{t}$ & - & - \\
\hline$\alpha$-pinene & 939 & - & - & - & 0.3 & $\mathrm{t}$ & - \\
\hline camphene & 954 & - & - & - & 0.6 & 0.2 & - \\
\hline sabinene & 975 & - & - & - & 0.1 & - & - \\
\hline$\beta$-pinene & 979 & 0.9 & - & - & 0.1 & 0.1 & - \\
\hline 2-carene & 1002 & 1.3 & - & 0.9 & - & - & - \\
\hline$\alpha$-phellandrene & 1003 & - & - & - & 0.1 & - & - \\
\hline terpinene & 1017 & - & - & - & 0.6 & 0.1 & - \\
\hline$p$-cymene & 1025 & - & 1.3 & - & 3.0 & 17.1 & - \\
\hline limonene & 1029 & 0.3 & - & - & - & 0.1 & - \\
\hline$\beta$-phellandrene & 1030 & - & - & - & 0.2 & - & - \\
\hline (Z)- $\beta$-ocimene & 1037 & - & - & - & - & $\mathrm{t}$ & - \\
\hline$\tau$-terpinene & 1048 & 3.4 & - & 1.9 & - & - & - \\
\hline$(E)$ - $\beta$-ocimene & 1050 & - & - & - & 3.8 & - & - \\
\hline$\gamma$-terpinene & 1060 & 1.4 & - & - & 0.6 & 3.7 & - \\
\hline m-cymene & 1085 & 39.2 & - & 0.6 & - & - & - \\
\hline \multicolumn{2}{|l|}{$\%$ identified } & 46.5 & 1.3 & 3.4 & 9.4 & 21.3 & - \\
\hline
\end{tabular}




\begin{tabular}{|c|c|c|c|c|c|c|c|}
\hline \multicolumn{8}{|c|}{ Oxygenated monoterpenes } \\
\hline eucalyptol & 1031 & 1.9 & - & 2.1 & - & $\mathrm{t}$ & - \\
\hline cis-sabinene hydrate & 1070 & - & - & - & 1.6 & - & - \\
\hline$\alpha$-terpinolene & 1089 & 0.5 & - & - & - & 0.5 & - \\
\hline trans-sabinene hydrate & 1098 & - & - & - & 0.4 & - & - \\
\hline pinene hydrate & 1123 & - & - & - & 1.0 & - & - \\
\hline limonene oxide & 1137 & 0.1 & - & - & - & - & 15.3 \\
\hline trans-pinocarveol & 1139 & 0.4 & - & - & - & - & - \\
\hline cis- $\beta$-terpineol & 1144 & 0.3 & - & - & 24.3 & - & - \\
\hline camphor & 1146 & - & 0.1 & - & - & 0.8 & - \\
\hline menthone & 1153 & - & - & - & 13.1 & - & - \\
\hline trans- $\boldsymbol{\beta}$-terpineol & 1163 & - & - & - & 0.3 & - & - \\
\hline borneol & 1169 & - & 7.1 & - & - & 16.0 & - \\
\hline 4-terpineol & 1177 & - & 0.5 & - & - & 1.3 & - \\
\hline$p$-cymene-8-ol & 1180 & - & - & - & 1.4 & - & - \\
\hline$\alpha$-terpineol & 1189 & - & 3.4 & - & - & 5.5 & - \\
\hline dihydrocarvone & 1190 & 0.4 & - & 1.9 & - & - & - \\
\hline myrtenol & 1196 & - & 0.2 & - & 0.3 & 0.3 & - \\
\hline linalyl formate & 1216 & 4.6 & - & - & - & - & - \\
\hline carveol-cis & 1229 & - & - & - & 0.8 & - & - \\
\hline carvone & 1243 & - & 9.1 & - & - & - & - \\
\hline carvacrol methyl ether & 1245 & - & - & - & 0.6 & - & - \\
\hline linalyl acetate & 1257 & 1.2 & - & - & - & - & - \\
\hline$p$-cymen-7-ol & 1287 & - & - & - & - & 2.3 & - \\
\hline bornyl acetate & 1289 & - & - & - & - & 1.6 & - \\
\hline carvacrol ethyl ether & 1298 & - & - & - & 0.8 & - & - \\
\hline isopulegyl acetate & 1335 & - & - & - & - & - & 19.8 \\
\hline carvacryl acetate & 1367 & 0.2 & - & - & - & - & - \\
\hline \multicolumn{2}{|c|}{$\%$ identified } & 9.6 & 20.4 & 4.0 & 44.6 & 28.3 & 35.1 \\
\hline \multicolumn{8}{|c|}{ Sesquiterpene hydrocarbons } \\
\hline$\alpha$-copaene & 1377 & - & - & - & 1.2 & - & - \\
\hline$\beta$-bourbonene & 1388 & - & - & - & 2.4 & 1.7 & - \\
\hline (Z)-caryophyllene & 1409 & - & 1.6 & - & - & 5.1 & - \\
\hline aromadendrene & 1437 & 11.8 & - & 23.7 & 8.4 & - & 15.7 \\
\hline$\alpha$-himachalene & 1451 & 0.2 & - & 12.0 & - & - & - \\
\hline$\alpha$-humulene & 1455 & - & - & - & 2.3 & - & - \\
\hline$(E)-\beta$-farnesene & 1457 & - & - & - & 2.9 & - & - \\
\hline allo-aromadendrene & 1458 & 24.8 & - & 15.2 & 0.5 & - & 5.0 \\
\hline germacrene-D & 1485 & - & 0.3 & - & 0.6 & 6.6 & - \\
\hline$\tau$-muurolene & 1480 & - & 0.6 & - & - & 20.1 & - \\
\hline$\gamma$-cadinene & 1514 & 0.3 & - & - & - & 0.9 & - \\
\hline$\alpha$-cadinene & 1539 & 0.5 & 0.1 & - & - & 0.4 & - \\
\hline \multicolumn{2}{|c|}{$\%$ identified } & 37.6 & 2.6 & 50.9 & 18.3 & 34.8 & 20.7 \\
\hline
\end{tabular}




\begin{tabular}{|c|c|c|c|c|c|c|c|}
\hline \multicolumn{8}{|l|}{ Oxygenated sesquiterpenes } \\
\hline bisabolene epoxide & 1504 & - & - & 3.3 & - & - & 5.6 \\
\hline spathulenol & 1572 & - & 0.8 & - & 1.6 & 8.5 & - \\
\hline caryophyllene oxide & 1583 & - & 0.6 & 4.2 & - & 4.0 & - \\
\hline viridiflorol & 1593 & - & - & - & - & 0.4 & 10.0 \\
\hline a-cadinol & 1660 & 1.1 & - & 7.6 & - & 0.7 & 27.8 \\
\hline \multicolumn{2}{|l|}{$\%$ identified } & 1.1 & 1.4 & 15.1 & 1.6 & 13.6 & 43.4 \\
\hline \multicolumn{8}{|l|}{ Phenolic compounds } \\
\hline tymol & 1290 & 1.2 & - & - & $\mathrm{t}$ & - & - \\
\hline carvacrol & 1299 & 2.8 & 72.1 & 16.2 & 3.3 & - & - \\
\hline \multicolumn{2}{|l|}{$\%$ identified } & 4.0 & 72.1 & 16.2 & 3.3 & - & - \\
\hline Total (\%) & & 98.8 & 99.8 & 94.1 & 99.8 & 99.0 & 99.2 \\
\hline
\end{tabular}

\subsection{Phenolic Contents}

Analysis of the phenolic components and quantity of the extracts of the species, which were prepared through (i) extraction of the shade-dried powdered plant with methanol (M1) and chloroform (C), (ii) extraction of the residual plant with acetone (Ac) and methanol (M2), were conducted using LC-MS/MS technique. Phenolic compounds were analyzed under three groups; (i) flavonoids and derivatives, (ii) coumaric acid and derivatives and (iii) simple phenolics and others. Compounds and their respective amounts per type are given in Tables 3-6. Methanol (M1 and M2) extracts, prepared by both techniques were found to be rich in quantity. These are followed by Ac and C respectively. Considering the chemical structures of the phenolic substances, it is obvious that they better dissolved in polar solvents.

Methanol (M1 and M2) and Ac extracts are very rich in coumaric acid and its derivatives. The most common compounds found in extracts are $(E)$-ferulic, caffeic and rosmarinic acids. Especially rosmarinic acid was found to be rich in Ac extracts of all members of Brevifilamentum section. Presence of rosmarinic acid in Lamiaceae members was reported in different studies [16, 54-55]. Flavonoids and their derivatives commonly exist in $\mathrm{C}$ extract, salvigenin and penduletin, which were reported previously in Origanum species [15], are the compounds of all types found in this extract. $\mathrm{OH}$ and $\mathrm{OA}$ are the richest species in terms of phenolic compounds. Based on the number of compounds, however, OA is the richest type with 24 types of different phenolic compounds, whereas OL type has the lowest number of compounds with 18 different compounds.

The most abundant compounds in the extracts are as follows: in M1 extract: rosmarinic acid for $\mathrm{OA}, \mathrm{OH}, \mathrm{OL}$ and $\mathrm{OR}$, fumaric acid for $\mathrm{OB}$ and $(E)$-ferulic acid for OHB. In M2 extracts: rosmarinic acid for $\mathrm{OA}, \mathrm{OL}$ and $\mathrm{OR}$, gallic acid for $\mathrm{OB},(E)$-ferulic acid for $\mathrm{OH}$, luteolin for OHB. In Ac extracts: rosmarinic acid was found to be the main compound of $\mathrm{OA}, \mathrm{OB}, \mathrm{OH}, \mathrm{OHB}$ and $\mathrm{OR}$, whereas kaempferol was found to be the main compound of OL species. In the poorest $\mathrm{C}$ extract, the main compound for $\mathrm{OA}$ and $\mathrm{OH}$ is quercetagetin-3,6-dimethylether, salvigenin for $\mathrm{OB}$ and $\mathrm{OHB}$ and penduletin for OL and OR.

\subsection{Activity}

The antioxidant activities were determined applying DPPH free radical scavenging activity, $\beta$ carotene linoleic acid assays and CUPRAC assays. Inhibition of lipid peroxidation and DPPH free radical scavenging effect were determined at $10,25,50$, and $100 \mu \mathrm{g} / \mathrm{mL}$.

Antioxidant activity results revealed that Brevifilamentum section has good antioxidant capacity for all applied three methods. For the CUPRAC method, OB showed the best activity (Figure 1). M2 extracts of $\mathrm{OB}$ had better activity than curcumin, which was used as standard. For especially 
the methanol extracts having 50 and $100 \mu \mathrm{g} / \mathrm{mL}$ concentrations, DPPH and $\beta$-carotene methods showed higher activities, and OA was found to be the one with the highest activity, which was followed by $\mathrm{OB}$ and $\mathrm{OH}$, especially with $\mathrm{M} 2$ extracts. The results are given in the Figure 2.

The anticholinesterase activities of M1, M2, C and Ac extracts were determined at $200 \mu \mathrm{g} / \mathrm{mL}$, and galantamine was used as a standard compound. It was observed that only OB inhibited AChE enzyme slightly. For BChE enzyme, except $\mathrm{OH}$, inhibition was not observed $\mathrm{M} 2$ extracts of the species. The species with the highest $\mathrm{BChE}$ inhibition is OA (Table 7).

It could be concluded that high activity observed in that species is associated with high amount of phenolic compounds. In $\mathrm{C}$ extracts, species with high amounts of quercetagetin-3.6dimethylether and salvigenin have better BChE inhibition values. Direct methanol (M1) and Ac extracts of these types have moderate $\mathrm{BChE}$ enzyme inhibition capacity.

Table 3. Phenolic contents of the M1 extracts

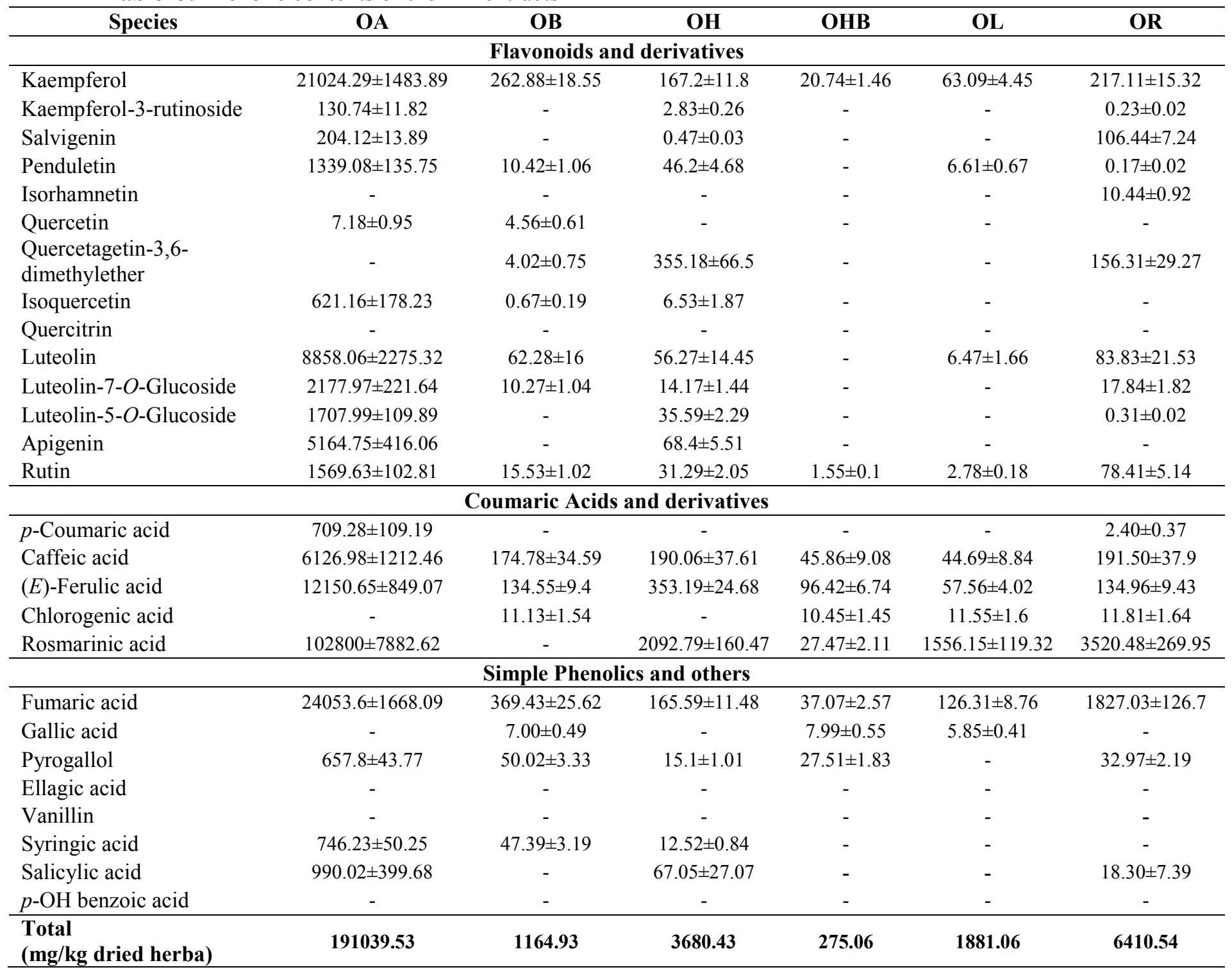


Table 4. Phenolic content of the M2 extracts

\begin{tabular}{|c|c|c|c|c|c|c|}
\hline Compounds & $\mathbf{O A}$ & OB & OH & OHB & $\mathbf{O L}$ & OR \\
\hline \multicolumn{7}{|c|}{ Flavonoids and derivatives } \\
\hline Kaempferol & $253.07 \pm 17.86$ & - & $162300 \pm 11455.09$ & - & $177.01 \pm 12.49$ & $57.88 \pm 4.09$ \\
\hline $\begin{array}{l}\text { Kaempferol-3- } \\
\text { rutinoside }\end{array}$ & - & - & $12174.51 \pm 1100.24$ & - & - & - \\
\hline Salvigenin & - & - & $648.93 \pm 44.16$ & - & - & - \\
\hline Penduletin & - & - & $4366.06 \pm 442.62$ & - & - & - \\
\hline Isorhamnetin & - & - & $592.15 \pm 52.26$ & - & - & - \\
\hline Quercetin & & - & $2104.05 \pm 279.72$ & - & - & - \\
\hline $\begin{array}{l}\text { Quercetagetin-3,6- } \\
\text { dimethylether }\end{array}$ & $24.05 \pm 4.50$ & - & $76700 \pm 14360.91$ & - & - & $0.52 \pm 0.1$ \\
\hline Isoquercetin & $6.69 \pm 1.92$ & - & $5749.28 \pm 1649.65$ & - & - & - \\
\hline Quercitrin & $31.58 \pm 2.01$ & - & - & - & - & - \\
\hline Luteolin & $95.9 \pm 24.63$ & - & $79350 \pm 20382.18$ & $430.84 \pm 110.7$ & $36.85 \pm 9.46$ & $16.00 \pm 4.11$ \\
\hline $\begin{array}{l}\text { Luteolin-7-O- } \\
\text { Glucoside }\end{array}$ & $50.18 \pm 5.11$ & - & $30083.67 \pm 3061.44$ & $207.93 \pm 21.16$ & $6.64 \pm 0.68$ & $2.48 \pm 0.25$ \\
\hline $\begin{array}{l}\text { Luteolin-5-O- } \\
\text { Glucoside }\end{array}$ & $22.29 \pm 1.43$ & - & $58400 \pm 3757.47$ & - & - & - \\
\hline Apigenin & $23.72 \pm 1.91$ & - & $33201.13 \pm 2674.60$ & - & - & - \\
\hline Rutin & $26.6 \pm 1.74$ & - & $14892.73 \pm 975.44$ & - & $6.54 \pm 0.43$ & $4.16 \pm 0.27$ \\
\hline \multicolumn{7}{|c|}{ Coumaric Acids and derivatives } \\
\hline$p$-Coumaric acid & - & $323.90 \pm 64.1$ & $4931.1 \pm 759.08$ & - & - & - \\
\hline Caffeic acid & $119.58 \pm 23.66$ & - & $190450 \pm 37687.79$ & $154.49 \pm 30.57$ & $125.75 \pm 24.89$ & $118.46 \pm 23.4$ \\
\hline (E)-Ferulic acid & $422.47 \pm 29.52$ & - & $399000 \pm 27881.52$ & - & $123.61 \pm 8.64$ & $92.74 \pm 6.48$ \\
\hline Chlorogenic acid & $37.49 \pm 5.19$ & $123.21 \pm 17.06$ & $11027.18 \pm 1527.00$ & $52.2 \pm 7.23$ & $9.68 \pm 1.34$ & $22.06 \pm 3.05$ \\
\hline Rosmarinic acid & $2494.15 \pm 191.25$ & - & - & - & $2105.32 \pm 161.43$ & $2634.67 \pm 22.02$ \\
\hline \multicolumn{7}{|c|}{ Simple Phenolics and others } \\
\hline Fumaric acid & $538.13 \pm 37.32$ & - & $117500 \pm 8148.5$ & - & $290.83 \pm 20.17$ & $1031.18 \pm 71.51$ \\
\hline Gallic acid & - & $487.27 \pm 33.79$ & - & $333.56 \pm 23.13$ & $6.24 \pm 0.43$ & - \\
\hline Pyrogallol & $21.06 \pm 1.40$ & - & $24833.91 \pm 1652.56$ & - & $22.03 \pm 1.47$ & $26.03 \pm 1.73$ \\
\hline Ellagic acid & - & - & - & - & - & - \\
\hline Vanillin & - & - & - & - & - & - \\
\hline Syringic acid & $10.9 \pm 0.73$ & - & $19628.58 \pm 1321.70$ & - & $9.58 \pm 0.65$ & - \\
\hline Salicylic acid & $21.43 \pm 8.65$ & - & $106550 \pm 43015.10$ & - & - & $48.75 \pm 19.68$ \\
\hline$p$-OH benzoic acid & $135.99 \pm 10.80$ & - & $32429.73 \pm 2576.46$ & - & - & $151.56 \pm 12.04$ \\
\hline $\begin{array}{l}\text { Total } \\
\text { (mg/kg dried herba) }\end{array}$ & 4335.28 & 934.38 & 1386912.28 & 1179.02 & 2920.08 & 4206.49 \\
\hline
\end{tabular}

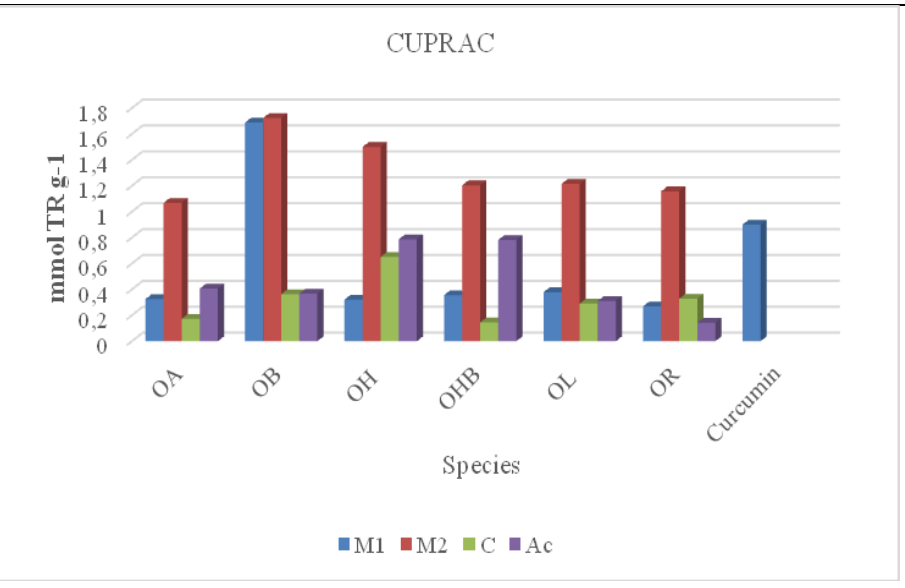

Figure 1. $\mathrm{Cu}^{2+}$ reducing power (CUPRAC) assay of the extracts and curcumin 
Table 5. Phenolic content of the $\mathrm{C}$ extracts

\begin{tabular}{|c|c|c|c|c|c|c|}
\hline Compounds & $\mathbf{O A}$ & OB & $\mathbf{O H}$ & OHB & OL & OR \\
\hline \multicolumn{7}{|c|}{ Flavonoids and derivatives } \\
\hline Kaempferol & - & - & $18.42 \pm 1.3$ & - & - & - \\
\hline Kaempferol-3-rutinoside & - & - & - & - & - & - \\
\hline Salvigenin & $4.41 \pm 0.3$ & $12.06 \pm 0.82$ & - & $18.16 \pm 1.24$ & $11.06 \pm 0.75$ & $69.84 \pm 4.75$ \\
\hline Penduletin & $20.56 \pm 2.08$ & $4.80 \pm 0.49$ & $14.6 \pm 1.48$ & $9.43 \pm 0.96$ & $81.83 \pm 8.3$ & $93.35 \pm 9.46$ \\
\hline Isorhamnetin & - & - & - & - & - & - \\
\hline Quercetin & - & - & - & - & - & - \\
\hline $\begin{array}{l}\text { Quercetagetin-3.6- } \\
\text { dimethylether }\end{array}$ & $38.82 \pm 7.27$ & - & $133.11 \pm 24.92$ & - & - & $87.42 \pm 16.37$ \\
\hline Isoquercetin & - & - & - & - & - & - \\
\hline Quercitrin & - & - & - & - & - & - \\
\hline Luteolin & - & - & - & - & - & - \\
\hline Luteolin-7-O-Glucoside & - & - & - & - & - & - \\
\hline Luteolin-5-O-Glucoside & - & - & - & - & - & - \\
\hline Apigenin & - & - & $9.64 \pm 0.78$ & - & - & - \\
\hline Rutin & - & - & - & - & - & - \\
\hline \multicolumn{7}{|c|}{ Coumaric Acids and derivatives } \\
\hline$p$-Coumaric acid & - & $7.91 \pm 1.56$ & - & - & - & - \\
\hline Caffeic acid & - & - & - & $6.24 \pm 1.23$ & $12.05 \pm 2.38$ & - \\
\hline (E)-Ferulic acid & - & - & - & - & - & - \\
\hline Chlorogenic acid & - & $6.83 \pm 0.95$ & - & $10.18 \pm 1.41$ & $7.8 \pm 1.08$ & - \\
\hline Rosmarinic acid & - & $3.37 \pm 0.26$ & - & $3.53 \pm 0.27$ & $3.63 \pm 0.28$ & - \\
\hline \multicolumn{7}{|c|}{ Simple Phenolics and others } \\
\hline Fumaric acid & - & - & - & - & - & - \\
\hline Gallic acid & - & - & - & - & - & - \\
\hline Pyrogallol & - & - & - & - & - & - \\
\hline Ellagic acid & - & - & - & - & - & - \\
\hline Vanillin & - & - & - & $4.7 \pm 0.43$ & $6.33 \pm 0.58$ & - \\
\hline Syringic acid & - & - & - & - & - & - \\
\hline Salicylic acid & - & - & - & - & - & - \\
\hline$p$-OH benzoic acid & - & - & - & $4.15 \pm 0.33$ & $5.49 \pm 0.44$ & - \\
\hline $\begin{array}{l}\text { Total } \\
\text { (mg/kg dried herba) }\end{array}$ & 63.79 & 34.97 & 175.77 & 56.39 & 128.19 & 250.61 \\
\hline
\end{tabular}


Table 6. Phenolic content of the Ac extracts

\begin{tabular}{|c|c|c|c|c|c|c|}
\hline Compounds & $\mathbf{O A}$ & $\mathbf{O B}$ & $\mathbf{O H}$ & ОНВ & OL & OR \\
\hline \multicolumn{7}{|c|}{ Flavonoids and derivatives } \\
\hline Kaempferol & $349.4 \pm 24.66$ & $1149.62 \pm 81.14$ & $85.38 \pm 6.03$ & $170.9 \pm 12.06$ & $577.63 \pm 40.77$ & $65.64 \pm 4.63$ \\
\hline Kaempferol-3-rutinoside & $3.83 \pm 0.35$ & $27.32 \pm 2.47$ & - & - & $2.49 \pm 0.23$ & - \\
\hline Salvigenin & - & - & - & $10.24 \pm 0.7$ & - & $16.08 \pm 1.09$ \\
\hline Penduletin & $4.17 \pm 0.42$ & $44.86 \pm 4.55$ & $18.8 \pm 1.91$ & $12.26 \pm 1.24$ & $54.7 \pm 5.55$ & $43.55 \pm 4.41$ \\
\hline Isorhamnetin & - & $71.15 \pm 6.28$ & - & $5.5 \pm 0.49$ & - & - \\
\hline Quercetin & $3.48 \pm 0.46$ & $79.15 \pm 10.52$ & - & $3.03 \pm 0.4$ & $7.9 \pm 1.05$ & - \\
\hline $\begin{array}{l}\text { Quercetagetin-3.6- } \\
\text { dimethylether }\end{array}$ & $10.25 \pm 1.92$ & $31.16 \pm 5.83$ & $179.49 \pm 33.61$ & - & - & $45.53 \pm 8.53$ \\
\hline Isoquercetin & - & - & - & - & - & - \\
\hline Quercitrin & - & - & - & - & - & - \\
\hline Luteolin & $134.77 \pm 34.62$ & $329.99 \pm 84.76$ & $22.36 \pm 5.74$ & $58.34 \pm 14.99$ & $129.97 \pm 33.38$ & $10.51 \pm 2.70$ \\
\hline Luteolin-7-O-Glucoside & $4.71 \pm 0.48$ & $31.71 \pm 3.23$ & - & - & - & - \\
\hline Luteolin-5-O-Glucoside & - & $8.84 \pm 0.57$ & - & - & - & - \\
\hline Apigenin & $67.05 \pm 5.40$ & - & $32.56 \pm 2.62$ & - & - & $21.19 \pm 1.71$ \\
\hline Rutin & $4.93 \pm 0.32$ & $9.24 \pm 0.61$ & $16.18 \pm 1.06$ & $8.21 \pm 0.54$ & $1.59 \pm 0.1$ & $1.45 \pm 0.09$ \\
\hline \multicolumn{7}{|c|}{ Coumaric Acids and derivatives } \\
\hline$p$-Coumaric acid & - & $96.55 \pm 19.11$ & - & $14.53 \pm 2.24$ & - & - \\
\hline Caffeic acid & $50.22 \pm 9.94$ & - & $65.62 \pm 12.99$ & $59.7 \pm 11.81$ & $32.39 \pm 6.41$ & $21.05 \pm 4.17$ \\
\hline (E)-Ferulic acid & $25.86 \pm 1.81$ & - & $27.69 \pm 1.94$ & $46.92 \pm 3.28$ & - & $9.02 \pm 0.63$ \\
\hline Chlorogenic acid & - & $7.16 \pm 0.99$ & - & $8.18 \pm 1.13$ & $6.78 \pm 0.94$ & - \\
\hline Rosmarinic acid & $574.02 \pm 44.02$ & $1404.50 \pm 107.7$ & $1056.84 \pm 81.04$ & $1002.22 \pm 76.85$ & $322.06 \pm 24.7$ & $78.67 \pm 6.03$ \\
\hline \multicolumn{7}{|c|}{ Simple Phenolics and others } \\
\hline Fumaric acid & - & - & - & $4.27 \pm 0.3$ & - & - \\
\hline Gallic acid & - & $8.78 \pm 0.61$ & - & $12.09 \pm 0.84$ & $5.40 \pm 0.37$ & - \\
\hline Pyrogallol & - & - & - & - & - & - \\
\hline Ellagic acid & - & $9.82 \pm 0.66$ & - & - & - & - \\
\hline Vanillin & $8.5 \pm 0.78$ & - & - & $46.38 \pm 4.24$ & $22.33 \pm 2.04$ & - \\
\hline Syringic acid & $9.49 \pm 0.64$ & $10.88 \pm 0.73$ & - & $18.04 \pm 1.21$ & $1.25 \pm 0.08$ & - \\
\hline Salicylic acid & - & - & - & - & - & - \\
\hline$p$-OH benzoic acid & - & - & - & $47.05 \pm 3.74$ & $22.83 \pm 1.81$ & - \\
\hline $\begin{array}{l}\text { Total } \\
\text { (mg/kg dried herba) }\end{array}$ & 1250.68 & 3320.73 & 1504.92 & 1527.86 & 1187.32 & 312.69 \\
\hline
\end{tabular}



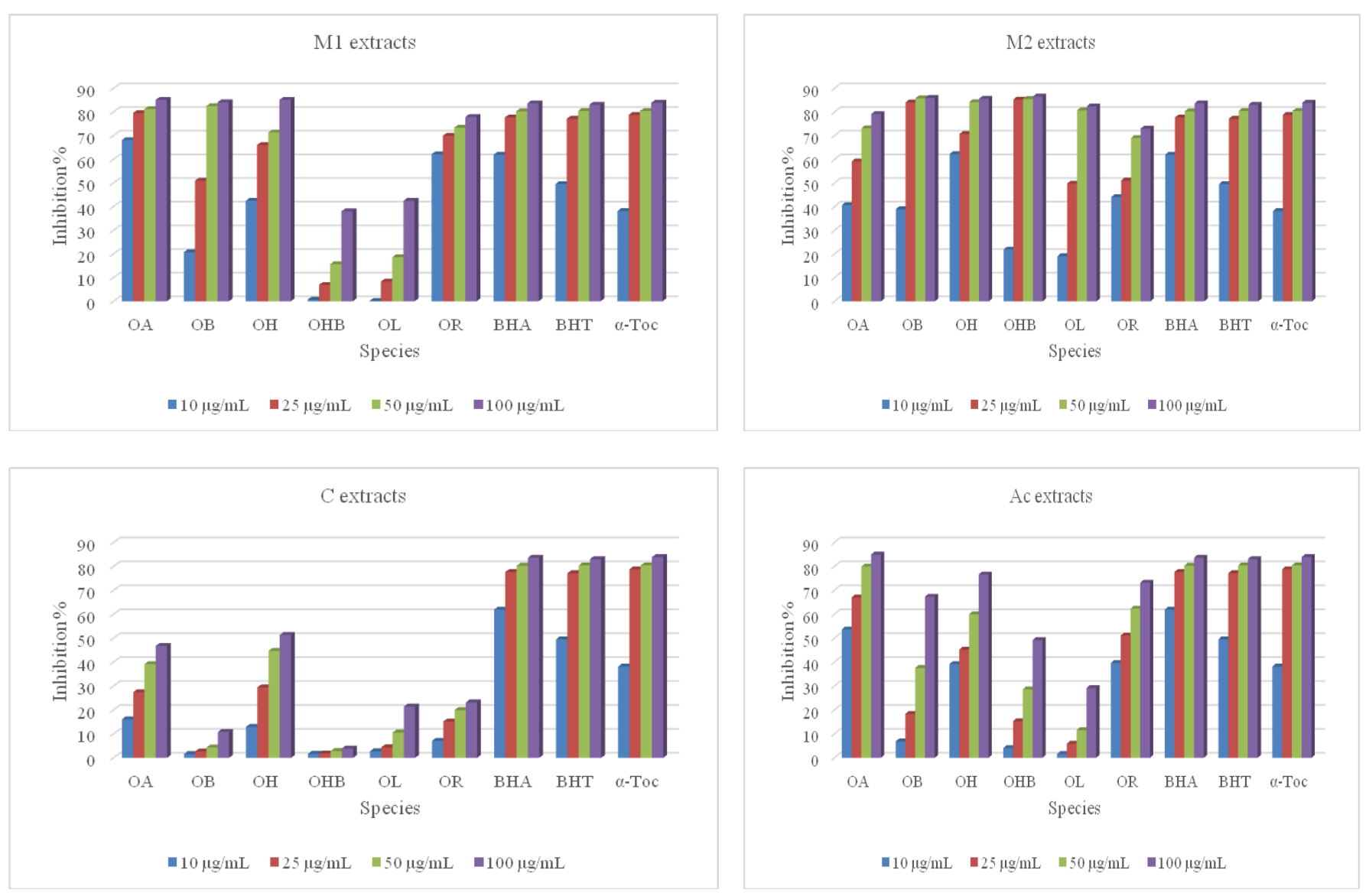

Figure 2. Antioxidant Activities of the extracts; DPPH free radical scavenging activity of the extracts and $\alpha$-Toc, BHA and BHT

Table 7. Anticholinesterase Activity of the the extracts

\begin{tabular}{|c|c|c|c|c|c|c|c|c|}
\hline & \multicolumn{8}{|c|}{ Inhibition\% $(200 \mu \mathrm{g} / \mathrm{mL})$} \\
\hline & \multicolumn{4}{|c|}{ AChE } & \multicolumn{4}{|c|}{ BChE } \\
\hline & M1 & $\mathbf{C}$ & Ac & M2 & M1 & $\mathbf{C}$ & Ac & M2 \\
\hline $\mathrm{OA}$ & 0 & 0 & 0 & 0 & $52.67 \pm 0.22$ & $50.64 \pm 0.21$ & $45.93 \pm 0.86$ & 0 \\
\hline OB & 0 & $33.48 \pm 1.23$ & $23.33 \pm 0.45$ & $5.59 \pm 0.29$ & $14.88 \pm 0.35$ & $35.20 \pm 0.93$ & $49.63 \pm 0.66$ & 0 \\
\hline $\mathrm{OH}$ & 0 & 0 & 0 & 0 & $41.08 \pm 0.79$ & $38.90 \pm 1.12$ & $31.47 \pm 0.58$ & $9.52 \pm 0.48$ \\
\hline OHB & 0 & 0 & 0 & 0 & $23.14 \pm 0.43$ & $33.49 \pm 1.65$ & $31.91 \pm 0.63$ & 0 \\
\hline $\mathrm{OL}$ & 0 & 0 & 0 & 0 & $8.44 \pm 0.16$ & $50.93 \pm 1.35$ & $47.97 \pm 0.62$ & 0 \\
\hline OR & 0 & 0 & 0 & 0 & $23.98 \pm 0.63$ & $36.22 \pm 0.82$ & $37.64 \pm 0.93$ & 0 \\
\hline $\begin{array}{c}\text { Control } \\
*\end{array}$ & $80.24 \pm 0.28$ & $82.10 \pm 0.51$ & $82.10 \pm 0.51$ & $80.24 \pm 0.28$ & $80.78 \pm 1.22$ & $82.05 \pm 0.48$ & $82.05 \pm 0.48$ & $80.78 \pm 1.22$ \\
\hline
\end{tabular}

* Galantamine used as a control. 

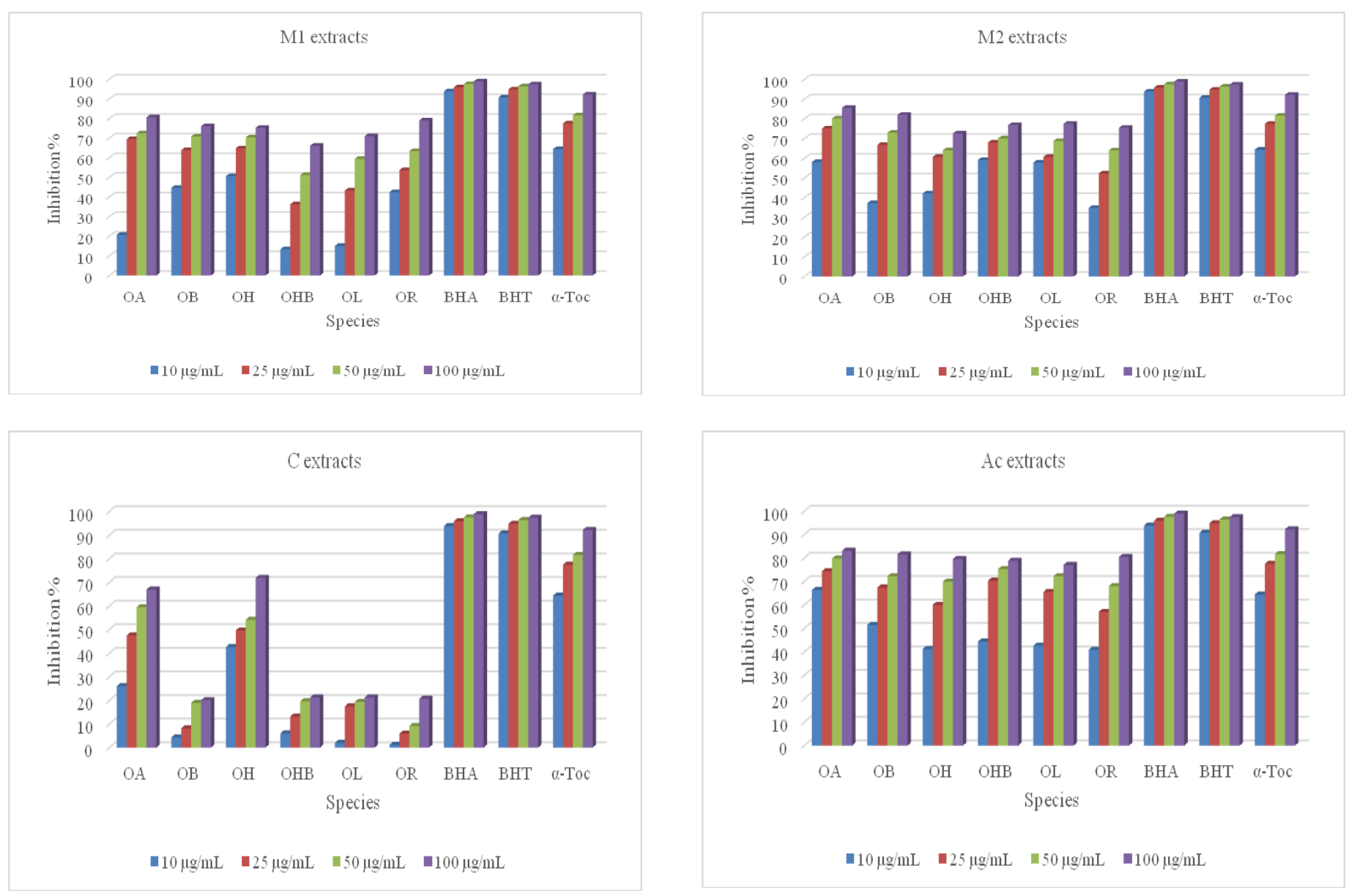

Figure 3. Inhibition (\%) of lipid peroxidation of the extracts and $\alpha$-Toc, BHA and BHT

In conclusion, we examined and reported the main essential oil, phenolic components and antioxidant and anticholinesterase activity of methanol, chloroform and acetone extracts of six Origanum species belonging to sect. Brevifilamentum, five of which are endemic to Turkey. Although there are numerous reports on the volatile compositions of these species, there is no report available on the phenolic composition. To the best of our knowledge, the phenolic compositions and activities of the extracts are reported for the first time. It has been shown that the oils of sect. Brevifilamentum are different types. However, when the phenolic compounds are considered, they are found to be rich in coumaric acid and its derivatives. Especially rosmarinic acid was the main compound of this section. Besides, the species which have rosmarinic acid in a high proportion showed the best activity. This study supported that Origanum species is very important species which are commonly used as spices, tea and alternative medicinal drug for many purposes throughout the world.

\section{Acknowledgments}

This work was supported by The Scientific and Technological Research Council of Turkey (TUBITAK) [grant number 113Z225].

\section{Supporting Information}

Supporting Information accompanies this paper on http://www.acgpubs.org/RNP 


\section{ORCID}

Ahmet C Goren: 0000-0002-5470-130X

\section{References}

[1] T. Baytop (1984). Türkiye'de bitkiler ile tedavi, İstanbul Üni. Yay. İstanbul-Türkiye. (In Turkish)

[2] A. Güner, S. Aslan, T. Ekim, M. Vural and M. Babaç (2012). Türkiye bitkileri listesi (damarlı bitkiler). Nezahat Gökyiğit botanik bahçesi ve flora araştırmaları derneği yayını. İstanbul. (In Turkish)

[3] T. Özcan, T. Dirmenci, F. Coşkun, E. Akçiçek and Ö. Güner (2015). A new species of Teucrium sect. Scordium (Lamiaceae) from SE of Turkey, Turk. J. Bot. 39, 310-317.

[4] M. Vural, H. Duman, T. Dirmenci and T. Özcan. (2015). A new species of Teucrium sect. Stachyobotrys (Lamiaceae) from the south of Turkey, Turk. J. Bot. 39, 318-324.

[5] H. Duman and T. Dirmenci (2017). A new species of Micromeria (Lamiaceae) from Köyceğiz (Muğla, southwest of Turkey), Turk. J. Bot. DOI: 10.3906/bot-1612-49 (in press)

[6] F. Celep and T. Dirmenci (2017). Systematic and Bio-Geographic Overview of Lamiaceae in Turkey. in Proceedings of International Symposium on Advances in Lamiaceae Science, Antalya, Turkey.

[7] [cited 15/04/2017]. Royal Botanic Gardens-Kew [Web Page] 2017; Available from: http:// http://www.kew.org/

[8] J. H. Ietswaart (1980). A taxonomic revision of the genus Origanum (Labiatae). Leiden Botanical Series. No. 4, Leiden University Press, Netherlands.

[9] T. Dirmenci, T. Yazıcı, T. Arabacı, S. Çelenk, T. Özcan and E. Dündar (2016). A new hybrid of Origanum L.: $O . \times$ dumanii Dirmenci, Arabac1 \& Yazıc1. in Proceedings of SEAB, Antalya, Turkey.

[10] T. Dirmenci, T. Yazıcı, T. Arabacı, S. Çelenk, T. Özcan and E. Dündar (2016). A new hybrid of Origanum L.: O. $\times$ bilgilii Dirmenci, Yazıc1 \& Arabac1, in Proceedings of SEAB, Antalya, Turkey.

[11] T. Dirmenci, T. Yazıcı, T. Arabacı, S. Çelenk, T. Özcan and E. Dündar (2016). A new species of Origanum L.: O. ayliniae Dirmenci, Akçiçek \&Yazıcı. in Proceedings of SEAB, Antalya, Turkey.

[12] T. Dirmenci, T. Yazıc1, T. Arabacı, S. Çelenk, T. Özcan and E. Dündar (2016). A new hybrid of Origanum L.: O. × adae Dirmenci, Yazıcı \& Akçiçek, in Proceedings of SEAB, Antalya, Turkey.

[13] K. H. C. Başer (2002). The Turkish Origanum Species. In: Oregano. The Genera Origanum and Lippia, (Ed. SE Kintzios). Taylor and Francis, London.

[14] P. K. Joshi, N. Joshi, G. Tewari and S. Tandon (2015). Chemical, biological and pharmacological aspects of Origanum species: A brief review, J. Indian. Chem. Soc. 92, 1603-1615.

[15] G. Özkan and M. M. Özcan (2014). Some phenolic compounds of extracts obtained from Origanum species growing in Turkey, Environ. Monit. Asses. 186, 4947-4957.

[16] A. Basli, J. C. Delaunay, E. Pedrot, S. Bernillon, K. Madani, J. P. Monti, J. M. Merillon, M. Chibane and R. Tristan (2014). New cyclolignans from Origanum glandulosum active against b-amyloid aggregation, Rec. Nat. Prod. 8(3), 208-216.

[17] S. Gülsoy (2012). Evaluation of essential oils and phenolic compounds of some Origanum (Labiatae/Lamiaceae) taxonomy, Asian J. Chem. 24(6), 2479.

[18] S. Chishti, A. Z. Kaloo and P. Sultan (2013). Medicinal impotance of genus Origanum: A review, J. Pharmacognosy Phytother. 5 (10), 170-177.

[19] K. H. C. Baser, G. Tümen and H. Duman (1997). The essential oil of Origanum acutidens (Hand.Mazz.) Iestwaart, J.Essent. Oil Res. 9, 91-92.

[20] K. H. C. Baser, T. Özek and G. Tümen (1995). The essential oil of Origanum rotundifolium Boiss., J. Essent. Oil Res. 7, 95-96.

[21] G. Figueredo, M. M. Ozcan, J. C. Chalchat, Y. Bagci, P. Chalard, F. Al Juhaimis and S. Dogu (2015). Chemical composition of essential oil from aerial parts and fruits of Hyssopus officinalis L., Origanum acutidens, Prangos uechritzii, H-hircinum L. and Hypericum polyphyllum subsp polyphyllum, Zeitschrift fur Arznei-\& Gewurzpflanzen, 20(4), 185-191

[22] G. Figuérédo, J. C. Chalchat and B. Pasquier (2006). Studies of Mediterranean oregano populations IX: chemical composition of essential oils of seven species of oregano of various origins, J. Essent. Oil Res. 18(4), 411-415.

[23] S. Kordali, B. Emsen and E. Yildirım (2013). Fumigant toxicity of essential oils from fifteen plant species against Sitophilus zeamais Motschulsky (Coleoptera: Curculionidae), Egyp. J. Biolog. Pest. Cont. 23(2), 241-246.

[24] O. Caglar, T. Calmasur, I. Aslan and O. Kaya (2007). Insecticidal effect of essential oil of Origanum acutidens against several stored product pests, Fresen. Environ. Bull. 16(11), 1395-1400. 
[25] M. Kesdek, S. Kordali, A. Usanmaz and S. Ercisli (2015). The toxicity of essential oils of some plant species against adults of colorado potato beetle, Leptinotarsa decemlineata Say (Coleoptera: Chrysomelidae), Comptes rendus de l'Académie bulgare des Sciences. 68(1), 127-136.

[26] M. Kesdek, N. Bayrak, S. Kordali, A. Usanmaz, G. Contuk and S. Ercisli (2013). Larvicidal Effects of some essential oils against larvae of the pine processionary moth, Thaumetopoea pityocampa (Denis \& Schiffermüller)(Lepidoptera: Thaumetopoeidae), Egyp. J. of Biolog. Pest Cont. 23(2), 201-207.

[27] T. Gokturk, S. Kordali, O. Calmasur and G. Tozlu (2011). Insecticidal effects of essential plant oils against larvae of great spruce bark beetle, Dendroctonus micans (Kugelann)(Coleoptera: Curculionidae: Scolytinae), Fres. Environ. Bull. 20, 2365-2370.

[28] S. Kordali, A. Cakir, H. Ozer, R. Cakmakci, M. Kesdek and E. Mete (2008). Antifungal, phytotoxic and insecticidal properties of essential oil isolated from Turkish Origanum acutidens and its three components, carvacrol, thymol and p-cymene, Bioresour. Technol. 99(18), 8788-8795.

[29] E. Tozlu, A. Cakir, S. Kordali, G. Tozlu, H. Ozer and T. A. Akcin (2011). Chemical compositions and insecticidal effects of essential oils isolated from Achillea gypsicola, Satureja hortensis, Origanum acutidens and Hypericum scabrum against broadbean weevil (Bruchus dentipes), Sci. Horticult. 130(1), 9-17.

[30] I. Goze, A. Alim, S. A. Cetinus, A. Cetin, N. Durmus, A.T. Atas and N. Vural (2010). In vitro antimicrobial, antioxidant, and antispasmodic activities and the composition of the essential oil of Origanum acutidens (Hand.-Mazz.) Ietswaart, J. Med. Food. 13(3), 705-709.

[31] I. Goze, A. Alim, A. S. Tepe, M. Sokmen, K. Sevgi and B. Tepe (2009). Screening of the antioxidant activity of essential oil and various extracts of Origanum rotundifolium Boiss. from Turkey, J. Med. Plants Res. 3(4), 246-254.

[32] M. Sökmen, J. Serkedjieva, D. Daferera, M. Gulluce, M. Polissiou, B. Tepe, H. A. Akpulat, F. Sahin and A. Sokmen (2004). In vitro antioxidant, antimicrobial and antiviral activities of the essential oil and various extracts from herbal parts and callus cultures of Origanum acutidens, J. Agri. Food Chem. 52(11), 3309-3312.

[33] M. Kurşat, I. Emre, Ö. Y1lmaz and P. Erecevit (2011). Antioxidant and antimicrobial activity in the seeds of Origanum vulgare L. subsp. gracile (C. Koch) Ietswaart and Origanum acutidens (Hand. Mazz.) Ietswaart from Turkey, Grasas Y. Aceites. 62(4), 410-417.

[34] B. Cetin, S. Cakmakci and R. Cakmakci (2011). The investigation of antimicrobial activity of thyme and oregano essential oils, Turk. J. Agri. Forest. 35(2), 145-154.

[35] F. Dadasoglu, T. Aydin, R. Kotan, A. Cakir, H. Ozer, S. Kordali, R. Cakmakci, N. Dikbas and E. Mete (2011). Antibacterial activities of extracts and essential oils of three Origanum species against plant pathogenic bacteria and their potential use as seed disinfectants, J. Plant Pathol. 93(2), 271-282.

[36] B. Cosge, A. Turker, A. Ipek and B. Gurbuz (2009). Chemical compositions and antibacterial activities of the essential oils from aerial parts and corollas of Origanum acutidens (Hand.-Mazz.) Ietswaart, an endemic species to Turkey, Molecules 14(5), 1702-1712.

[37] K. H. C. Baser, M. Kürkçüoglu and G. Tümen (1998). Composition of the essential oil of Origanum haussknechtii Boiss., J. Essent.Oil Res.10, 227-228.

[38] K. H. C. Baser, M. Kürkçüoglu, H. Duman and Z. Aytaç (1998). Composition of the essential oil of Origanum husnucan-baseri H.Duman, Z.Aytaç et A.Duran, a new species from Turkey, J.Essent. Oil Res. 10, 419-421.

[39] B. Uysal, F. Sozmen, E. O. Kose, I. Gokhan Deniz and B. S. Oksal (2010). Solvent-free microwave extraction and hydrodistillation of essential oils from endemic Origanum husnucanbaseri H. Duman, Aytaç \& A. Duran: comparison of antibacterial activity and contents, Nat. Prod. Res. 24(17), 16541663.

[40] K. H. C. Baser, N. Ermin, T. Özek, B. Demirçakmak, G. Tümen and H. Duman (1996). Essential oils of Thymbra sintenisii Bornm. et Aznav. subsp. isaurica P.H.Davis and Origanum leptocladum Boiss., J.Essent. Oil Res. 8, 675-676.

[41] N.Tanker, F.Ilisulu, M.Koyuncu and M.Coskun (1986). Phytochemical screening of plants from the Ermenek-Mut-Gülnar (Turkey) area. III Labiatae, Int. J. Crude Drug Res. 24 (4), 177-182.

[42] A. C. Goren, F. Piozzi, E. Akcicek, T. Kılıç, S. Çarıkçı, E. Mozioğlu and W. N. Setzer (2011). Essential oil composition of twenty-two Stachys species (mountain tea) and their biological activities, Phytochem. Lett. 4, 448-453.

[43] S. D. Hatipoglu, N. Zorlu, T. Dirmenci, A. C. Goren, T. Ozturk and G. Topcu (2016). Determination of volatile organic compounds in forty-five Salvia species by thermal desorption-GC-MS technique, Rec. Nat. Prod. 10, 659-700. 
[44] R. P. Adams (2007). Identification of essential oil components by gas chromatography/mass Spectrometry. 4th Ed., Allured Publishing Corp., Carol Stream, Illinois.

[45] A. C. Gören, S. Çıkrıkçı, M. Çergel and G. Bilsel (2009). Rapid quantitation of curcumin in turmeric via NMR and LC-tandem mass spectrometry, Food Chem. 113, 1239-1242.

[46] A. C. Goren, G. Bilsel and M. Bilsel (2007). Rapid and simultaneous determination of 25-OH-vitamin D2 and D3 in human serum by LC/MS/MS: validation and uncertainty assessment, J. Chem. Metrol. 1, $1-10$.

[47] P. Kalin, I. Gulcin and A. C. Goren (2015). Antioxidant activity and polyphenol content of Cranberries (Vaccinium macrocarpon), Rec. Nat. Prod. 9, 496-502.

[48] G. L. Ellman, K. D. Courtney, V. Andres and R. M. Featherston (1961). A new and rapid colorimetric determination of acetylcholinesterase activity, Biochem. Pharma. 7, 88-95.

[49] A. Yilmaz, M. Boga and G. Topçu (2016). Novel terpenoids with potential anti-alzheimer activity from Nepeta obtusicrena., Rec. Nat. Prod. 10(5), 530-541.

[50] N.B. Reddy, C.S. Sundar, S.H. Jayaprakash, G.Mohan, P.V.Reddy and C.S.Reddy (2016). Synthesis and antioxidant activity of dioxazaphosphinin-2-ones, Org.Commun. 8, 17-23

[51] M. S. Blois (1958). Antioxidant determinations by the use of a stable free radical, Nature 181, 11991200 .

[52] A. Ertas, A. C. Gören, N. Hasimi, V. Tolan and U. Kolak (2015). Evaluation of antioxidant, cholinesterase inhibitory and antimicrobial properties of Mentha longifolia subsp. noeana and its secondary metabolites, Rec. Nat. Prod. 9(1), 105-115.

[53] N.B. Reddy, C.S. Sundar, S.H. Jayaprakash, G. Mohan, P.V. Reddy and C.S. Reddy (2015). Synthesis and antioxidant activity of dioxazaphosphinin-2-ones, Org. Commun. 8, 17-23.

[54] R. Apak, K. Güçlü, M. Özyürek and S. E. Karademir (2008). Mechanism of antioxidant capacity assays and the CUPRAC (cupric ion reducing antioxidant capacity) assay, Microchim. Acta. 160, 413-419.

[55] B. Sreedhar, T.V. Reddy, C.N. Raju and G.V.S. Reddy (2016). Design, synthesis, characterization and bioassay of novel carboxamide derivatives of celecoxib, Org. Commun. 9, 54-64

[56] D. Benedec, D. Hanganu, I. Oniga, B. Tiperciuc, N. K. Olah, O. Raita, C. Bischin, R. SilaghiDumitrescu and L. Vlase (2015). Assessment of rosmarinic acid content in six Lamiaceae species extracts and their antioxidant and antimicrobial potential, Pak. J. Pharm. Sci. 28, 2297-2303.

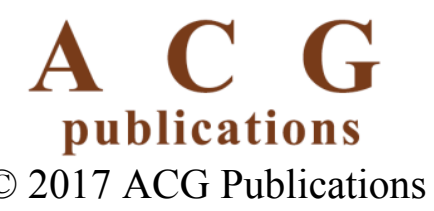

